\title{
Pelangaran Outsourcing Yang Dapat Dikategorikan Sebagai Tindak Pidana Perdagangan Orang
}

\author{
Alexander Simon Pally \\ Program Magister Ilmu Hukum Pascasarjana Universitas Airlangga, Surabaya, Indonesia \\ E-mail: alexspally@gmail.com
}

\begin{abstract}
This study discusses Outsourcing violations which can be categorized as Trafficking in Persons. In this writing, outsourcing workers employed need to get legal protection in accordance with the mandate of Article 27 paragraph (2) of the 1945 Constitution stating "Every citizen has the right to work and remuneration that is appropriate for humanity" and Article 28D paragraph (2) asserting that "every person has the right to work and receive compensation and fair and proper treatment in employment relations" outsourcing workers who work outside and / or exceed working hours, and the recruitment of the wrong workers need to be sanctioned as a form of protection for workers. Based on Article 65 paragraph (6) of Law Number 13 of 2003, this study uses the Normative Juridical research method which uses library legal materials and in the results of its research the researcher gets the implementation of the outsourcing system work relations occur, namely between labor, employer, and providers of labor or outsourcing companies. The Crime of Trafficking in Persons is possible to occur when from the process of recruitment of workers, appropriation of workers and remuneration of workers.
\end{abstract}

Keywords: Outsourcing Violations, Criminal Trafficking In Persons

\section{A. PENDAHULUAN}

Perkembangan

globalisasi, khususnya dibidang ketenagakerjaan bermuatan ekses positif maupun negatif, dalam hal ini perlu adanya peran hukum dalam kehidupan bermasyarakat, sehubungan dengan potensi kriminal terkait dengan Pelaksanaan pekerjaan Alih Daya (Outsourcing) hukum pidana dan penegakannya merupakan bagian dari

1 Muladi. (1990) Proyeksi Hukum Pidana Materiil Di Indonesia Masa Mendatang, Pidato politik kriminal (crime policy), politik kriminal merupakan bagian dari politik penegakan hukum law enforcement policy) yang mencangkup pula penegakan hukum perdata dan penegakan hukum administrasi. Politik penegakan hukum merupakan bagian dari politik sosial (social policy )yang merupakan usaha setiap masyarakat dan negara untuk meningkatkan kesejahteraan warganya ${ }^{1}$.

Pengukuhan Guru Besar, (Semarang: Universitas Diponegoro), h. 6 
Hal ini sejalan dengan systematic approach to crime prevention planning sebagaimana diintruksi oleh kongres PBB VII mengenai the prevention of crime and treatment of offenders. ${ }^{2}$

Di abad 21 istilah Globalisasi, Demokratisasi, dan Hak Asasi Manusia sudah tidak asing di telinga orang namun kita juga melihat memuncaknya teknologi modern dan keunggulan ilmu pengetahuan mutakhir telah menimbulkan berbagai masalah yang tidak pernah kita duga sebelumnya, jika kita melihat sejarah sebagai suatu sistem sirkulasi, kita akan menemukan bahwa dalam sistem dan sirkulasi ini terdapat sebuah pola - pola yang berulang.

Problematika purba kala yang menjadikan manusia bukan sebagai subjek yang menguasai segalanya namun menepatkan manusia hanya sebagai objek seperti barang yang dapat di perjual belikan, sejarah mencatat dalam perkembagan dunia menuju era modern banyak terdapat contoh yang dapat dijadikan acuan bahwa Perdagangan manusia sudah ada berabad - abad yang lalu, abad ini merupakan abad yang mengubah sebagian besar dunia dari era pertanian (agrikultur) ke era industri. Jika melihat sejarah perdagangan orang sebagai sebuah sirkulasi maka pada jaman dahulu seorang yang di jual dan dijadikan sebagai budak kemudian berkerja di sektor pertanian seperti bekerja diladang atau dikerjakan sebagai di sektor perternakan perdagangan manusia di dunia barat pun terjadi seperti perdagangan orang berkulit hitam untuk dijadikan pekerja di kebun kopi, atau sebagai tontonan pergulatan antara maunsia dengan binatang buas bahkan manusia di perlakukan lebih buruk dari pada binatang.

Di jaman modern sekarang perdagangan orang lebih pada modus memberikan kesempatan kerja namun pada kenyataannya tidak di pekerjakan

2 Supanto, Prespektif Hukum Pidana Menghadapi Perkembangan Kejahatan Ekonomi sebagaimana mestinya bahkan di perlakukan lebih buruk, dalam praktiknya, implementasi outsourcing banyak yang dilanggar oleh perusahaan. Pelanggaran tersebut mulai dari upah, jam kerja, serta pekerjaan yang di-outsourcing-kan. Pelanggaran ini tidak hanya dilakukan oleh instansi swasta, namun juga oleh instansi pemerintah.

Berdasarkan uraian latar belakang diatas, maka permasalahannya adalah: "Bagaimana bentuk-bentuk pelanggaran terhadap ketentuan outsourcing yang dapat dikategorikan sebagai tindak pidana perdagangan orang".

\section{B. PEMBAHASAN}

Perjanjian menurut Pasal 1313 Burgerlijk Wetboek (BW) adalah suatu perbuatan dengan mana satu orang atau lebih mengikatkan dirinya terhadap satu orang atau lebih. Peristiwa ini menimbulkan suatu hubungan antara dua orang tersebut yang dinamakan perikatan. Setiap perjanjian akan menimbulkan suatu perikatan antara dua orang yang membuatnya.

Pasal 1320 ayat (1) BW menyebutkan beberapa syarat sahnya suatu perjanjian di antaranya adalah sepakat mereka yang mengikatkan dirinya, kecakapan untuk membuat suatu perikatan, suatu hal tertentu, dan suatu sebabyang halal. Perjanjian yang dibuat secara sah berlaku sebagai Undang-Undang bagi mereka yang membuatnya. Begitu pula dengan perjanjian kerja terhadap pihakpihak yang terlibat di dalamnya. Perjanjian kerja (arbeidsoverenkoms), menurut Pasal 1601 a BW adalah perjanjian dengan mana pihak kesatu, si buruh mengikatkan dirinya untuk di bawah perintah pihak yang lain si majikan, untuk suatu waktu tertentu, melakukan pekerjaan dengan menerima upah. Sehubungan dengan itu, Undang-undang

Global, h.. 12. 
Nomor 13 Tahun 2003 tentang Ketenagakerjaan, Pasal 1 angka 14 memberikan pengertian perjanjian kerja adalah perjanjian antara pekerja/buruh dengan pengusaha atau pemberi kerja yang memuat syarat-syarat kerja, hak, dan kewajiban para pihak.

Subekti memberikan pengertian tentang perjanjian kerja yaitu perjanjian antara seorang buruh dengan seorang majikan, perjanjian mana ditandai oleh ciri-ciri, adanya suatu upah atau gaji tertentu yang diperjanjikan dan adanya suatu hubungan diperatas (dierstverhanding), yaitu suatu hubungan berdasarkan mana pihak yang satu (majikan) berhak memberikan perintahperintah yang harus ditaati oleh pihak yang lain. ${ }^{3}$

Asas kebebasan berkontrak dalam hukum perjanjian Indonesia menurut Sutan Remi Sjahdeini meliputi ruang lingkup sebagai berikut: ${ }^{4}$

1) Kebebasan untuk membuat atau tidak membuat perjanjian.

2) Kebebasan untuk memilih pihak dengan siapa ia ingin membuat perjanjian.

3) Kebebasan untuk menentukan atau memilih kuasa dari perjanjian yang akan dibuatnya.

4) Kebebasan untuk menentukan obyek dari suatu perjanjian.

5) Kebebasan untuk menentukan bentuk suatu perjanjian.

6) Kebebasan untuk menerima atau menyimpangi ketentuan-ketentuan undang-undang yang bersifat opsional (aanvullend, optional).

Hubungan kerja adalah hubungan perdata yang didasarkan pada kesepakatan antara tenaga kerja dengan pemberi pekerjaan atau pengusaha. Oleh karena itu, bukti bahwa seseorang bekerja pada orang lain atau pada sebuah perusahaan/lembaga

3 Subekti, R. (1977). Aneka Perjanjian, Bandung: Alumni, h. 63.

4 Hernoko, Agus Yudha. (2010). Hukum Perjanjian Asas Proporsionalitas dalam Kontrak adalah adanya perjanjian kerja yang berisi tentang hak-hak dan kewajiban masingmasing baik sebagai pengusaha maupun sebagai tenaga kerja. Ada dua bentuk perjanjian kerja, yaitu:

a. Perjanjian Kerja Secara Lisan

Perjanjian kerja umumnya secara tertulis, akan tetapi masih ada juga perjanjian kerja yang disampaikan secara lisan. Undang-undang Nomor 13 Tahun 2003 tentang Ketenagakerjaan (UUKK) membolehkan perjanjian kerja dilakukan secara lisan, dengan syarat pengusaha wajib membuat surat pengangkatan bagi pekerja, yang berisi:

1) Nama dan alamat pekerja

2) Tanggal mulai bekerja

3) Jenis pekerjaan

4) Besarnya upah (Pasal 63 Undang-undang Nomor 13 Tahun 2003 tentang Ketenagakerjaan).

Pekerjaan-pekerjaan yang dapat diselesaikan dalam waktu tertentu dan pengusaha bermaksud memperkerjakan pekerja untuk waktu tertentu (PKWT), perjanjian kerja tidak boleh dibuat secara lisan. $^{5}$

b. Perjanjian Kerja Tertulis

Perjanjian kerja tertulis harus memuat tentang jenis pekerjaan yang akan dilakukan, besarnya upah yang akan diterima dan berbagai hak serta kewajiban lainnya bagi masing-masing pihak. Perjanjian kerja tertulis harus secara jelas menyebutkan apakah perjanjian kerja itu termasuk Perjanjian Kerja Waktu Tertentu (PKWT atau disebut sistem kontrak) atau Perjanjian

Komersial, Jakarta: Kencana Prenada Media Group, h. 110-111

5 Jehani, Libertus. (2006). Hak-Hak Pekerja Bila di PHK, Jakarta: Visimedia, h. 3 


Kerja Waktu Tidak
(PKWTT Tertentu
permanen/tetap). ${ }^{6}$

Sama seperti perjanjian pada umumnya, perjanjian kerja harus didasarkan pada:

a) Kesepakatan kedua belah pihak untuk melakukan hubungan kerja.

b) Kecakapan para pihak untuk melakukan perbuatan hukum.

c) Adanya pekerjaan yang diperjanjikan.

d) Pekerjaan yang diperjanjikan tersebut tidak bertentangan dengan ketertiban umum, kesusilaan, dan peraturan perundang-undangan yang berlaku.

Selain itu, perjanjian kerja tidak boleh bertentangan dengan Perjanjian Kerja Bersama (PKB), yaitu perjanjian yang dibuat oleh pengusaha dan pekerja/serikat pekerja yang disahkan oleh pemerintah (Instansi Ketenagakerjaan). ${ }^{7}$ Syarat dan ketentuan pemborongan pekerjaan diatur dan ditetapkan berdasarkan hukum perjanjian, yakni kesepakatan kedua belah pihak.

Asas yang berlaku dalam hukum perjanjian adalah, hal-hal yang telah disepakati kedua belah pihak dalam perjanjian berlaku sebagai undang-undang yang mengikat. Ketentuan tersebut dikenal dengan Asas Kebebasan Berkontrak. ${ }^{8}$ Namun demikian, sekali pun undang-undang memberikan kebebasan kepada pihak-pihak untuk menentukan isi perjanjian pemborongan pekerjaan, syarat dan ketentuan perjanjian tidak boleh bertentangan dengan undangundang, kesusilaan dan norma keadilan.

Perjanjian kerja dibagi menjadi dua yaitu:

\footnotetext{
6 Ibid.

7 Ibid., h. 4

8 Damanik, Sehat. (2006). Outsourcing \&
} Perjanjian Kerja menurut UU. No.13 Tahun 2003 tentang Ketenagakerjaan, Jakarta: DSS Publishing., h. 10. a) Perjanjian Kerja Waktu Tertentu (PKWT)

b) Perjanjian Kerja Waktu Tidak Tertentu (PKWTT)

Perjanjian kerja untuk waktu tertentu dibuat bagi hubungan kerja yang dibatasi oleh jangka waktu berlakunya perjanjian atau selesainya pekerjaan itu.Untuk perjanjian kerja waktu tidak tertentu dibuat untuk hubungan kerja yang tidak dibatasi oleh jangka waktu berlakunya perjanjian atau selesainya pekerjaan tertentu. ${ }^{9}$

PKWT itu identik dengan pemborongan pekerjaan, yang dalam bahasa sehari-hari sering disebut sebagai pekerja kontrak. Jangka waktu berlaku perjanjian, apabila sudah habis, maka dengan sendirinya terjadi PHK dan para pekerja tidak berhak mendapat kompensasi PHK seperti uang pesangon, uang penghargaan masa kerja, uang penggantian hak, uang pisah. Jangka waktu PKWT itu berakhir secara otomatis apabila jangka waktu yang telah diperjanjikan itu jatuh tempo kecuali dalam hal dilakukan perpanjangan kontrak. Hal ini pun harus mengikuti dan tunduk pada ketentuan undang-undang dan tata cara perpanjangan kontrak. ${ }^{10}$

Pasal 1603 huruf e ayat (1) BW mengatur tentang untuk waktu tertentu: "Hubungan kerja berakhir demi hukum jika habis waktunya yang ditetapkan dalam perjanjian atas peraturan-peraturan atau dalam perundang-undangan atau jika semua itu tidak ada menurut kebiasaan.”Dengan demikian, perjanjian kerja waktu tertentu dibagi juga menjadi tiga yaitu:

1) Perjanjian kerja waktu tertentu, ada waktu berlakunya ditentukan menurut perjanjian.

9 Ramli, Lanny. (2008). Hukum Ketenagakerjaan, Surabaya: Airlangga University Press, h. 26

10 Samaloisa, Rinto W. (2016). Outsourcing Kontradiksi antara Konsep Hukum dan Praktik, Jakarta: Media Nusa Creative, h. 4849. 
2) Perjanjian kerja waktu tertentu, waktu berlakunya ditentukan menurut undang-undang.

3) Perjanjian kerja waktu tertentu, waktu berlakunya ditentukan menurut kebiasaan.

Perjanjian kerja untuk waktu tidak tertentu adalah perjanjian kerja di mana waktu berlakunya tidak ditentukan baik dalam perjanjian, undang-undang ataupun dalam kebiasaan.

Perjanjian kerja waktu tidak tertentu hanya dapat diadakan untuk pekerjaan tertentu menurut sifat, jenis atau kegiatannya akan selesai dalam jangka waktu tertentu, yaitu: ${ }^{11}$

a) Yang selesai sekali atau sementara sifatnya.

b) Yang diperkirakan untuk waktu yang tidak terlalu lama akan selesai.

c) Yang bukan merupakan kegiatan pokok suatu perusahaan atau hanya merupakan penunjang.

d) Yang berhubungan dengan produk baru, kegiatan baru, tambahan yang masih dalam percobaan atau penjajangan

\section{Pelanggaran Terhadap Pengupahan Perkerja Outsorcing}

Peraturanperundang-undangan ketenagakerjaan melarang pengusaha untuk melakukan diskriminasi terhadap pekerja baik pekerja PKWT atau PKWTT sebagaimana diatur dalam Pasal 88 sampai dengan Pasal 98 Undang-undang Nomor 13 Tahun 2003. Dengan demikian, upah dan kesejahteraan pekerja outsourcing secara normatif sebenarnya tidak berbeda dengan pekerja tetap (PKWTT). Besar gaji tidak boleh lebih rendah dari pada ketentuan peraturan perundang-undangan atau sekurangkurangnya sama dengan pekerja atau buruh tetap pada perusahaan pemberi

11 Kosidin, Koko. (1999). Perjanjian Kerja Perjanjian Perburuhan dan Peraturan pekerjaan. Hal ini dipertegas dalam ketentuan Pasal 65 ayat (4) dan Pasal 66 ayat (2) c Undang-undang Nomor 13 Tahun 2003. Dasar acuan penetapan upah adalah Upah Minimum Regional (UMR) sesuai daerah masing-masing.

Perusahaan yang mau melaksanakan outsourcing, tapi tidak mau ikut aturan mainnya. Misalnya gaji tidak dibayarkan sesuai UMR (Upah Minimum Regional), tidak memberikan tunjangan yang sesuai, tak mengikutkan pekerja Jamsostek atau sekarang namanya BPJS Ketenagakerjaan.

Menurut Pasal 1 ayat 30 UU No. 13 Tahun 2003 tentang Ketenagakerjaan, Upah adalah hak pekerja/buruh yang diterima dan dinyatakan dalam bentuk uang sebagai imbalan dari pengusaha atau pemberi kerja kepada pekerja/buruh yang ditetapkan dan dibayarkan menurut suatu perjanjian kerja, kesepakatan, atau peraturan perundang-undangan, termasuk tunjangan bagi pekerja/buruh dan keluarganya atas suatu pekerjaan dan/atau jasa yang telah atau akan dilakukan.

Namun, dalam menetapkan besarnya upah, pengusaha dilarang membayar lebih rendah dari ketentuan upah minimum yang telah ditetapkan pemerintah setempat (Pasal 90 ayat $1 \mathrm{UU}$ No. 13/ 2003). Apabila pengusaha memperjanjikan pembayaran upah yang lebih rendah dari upah minimum, maka kesepakatan tersebut batal demi hukum (Pasal 91 ayat 2 UU No. 13/2003)

Setiap pekerja/buruh berhak memperoleh penghasilan yang memenuhi penghidupan yang layak bagi kemanusiaan (Pasal 88 ayat 1 No. 13/2003). Kebijakan pemerintah mengenai pengupahan yang melindungi pekerja/buruh meliputi:

a) upah minimum;

b) upah kerja lembur;

c) upah tidak masuk kerja karena berhalangan; 
d) upah tidak masuk kerja karena melakukan kegiatan lain di luar pekerjaannya;

e) upah karena menjalankan hak waktu istirahat kerjanya;

f) bentuk dan cara pembayaran upah;

g) denda dan potongan upah;

h) hal-hal yang dapat diperhitungkan dengan upah;

i) struktur dan skala pengupahan yang proporsional;

j) upah untuk pembayaran pesangon; dan

k) upah untuk perhitungan pajak penghasilan.

Komponen upah sendiri terdiri dari upah pokok dan tunjangan tetap, maka besarnya upah pokok sedikit-dikitnya $75 \%$ dari jumlah upah pokok dan tunjangan tetap (Pasal 94 UU No. 13/2003).

Faktor-faktor yang Mempengaruhi Tingkat Upah:

1) Tingkat Persaingan

2) Biaya Keperluan Hidup

3) Peraturan UU tentang UMR

4) Perbedaan jenis pekerjaan

5) Produktifitas marginal.

Syarat dan tujuan pemberian upah syarat dalam pemberian upah adalah mampu memberikan kepuasaan kepada pekerja artinya mampu memberikan upah yang sebanding dengan perusahaan yang sama, adil, dan menyadari fakta bahwa setiap orang memiliki perbedaan akan kebutuhan. Sedangkan tujuan dalam pemberian upah adalah untuk memacu ketertarikan para tenaga kerja yang berbakat untuk masuk keperusahaan. Meningkatkan loyalitas dan mempertahankan pekerja yang berbakat serta memberikan motivasi kepada pekerja.

12 Hidayati, Maslihati Nur. (2012). "Upaya Pemberantasan dan Pencegahan Perdagangan Orang melalui Hukum Internasional dan Hukum

\section{Kejahatan Proses Perekrutan Pekerja Outsourcing.}

Pada tanggal 5 Maret 2009, pemerintah Indonesia meratifikasi Protokol Palermo melalui UndangUndang Nomor 14 Tahun 2009, dengan Declaration (Pernyataan) terhadap Pasal 5 ayat (2) huruf c dan Reservation (Pensyaratan) terhadap Pasal 15 ayat (2).107 Sedangkan sejak 12 Januari 2009, diberlakukan UU Nomor 5 Tahun 2009 tentang Pengesahan the United Nations Convention against Transnational Organized Crime (Konvensi PBB Menentang Tindak Pidana Transnasional yang Terorganisasi). Dan pada 16 Maret 2009, Indonesia memberlakukan UU Nomor 15 Tahun 2009 tentang Pengesahan the Protocol to Prevent, Suppress and Punish Trafficking in Persons, Especially Women and Childrean, Supplementing the United Nations Convention against Transnational Organized Crime. ${ }^{12}$

Pasal 3 Protokol Palermo berbunyi sebagai berikut:

a) Perdagangan orang (trafficking in persons) memiliki arti perekrutan, transportasi, pemindahan tangan, penyembunyian atau penerimaan manusia, melalui cara ancaman atau penggunaan kekerasan atau bentuk lainnya dari paksaan, penculikan, pemalsuan, penipuan, atau penyalahgunaan wewenang atau posisi kerentanan atau pemberian atau penerimaan bayaran atau keuntungan dalam rangka mendapatkan persetujuan pihak yang memiliki kendali atas manusia lain, untuk tujuan eksploitasi. Eksploitasi meliputi, setidaknya, eksploitasi atas prostitusi manusia lain atau bentuk eksploitasi seksual lainnya, kerja atau pelayanan secara paksa, perbudakan atau praktek-

Positif di Indonesia", Jurnal Al Azhar Indonesia, Seri Pranata Sosial, Vol 1 No 3, Maret, h. 164. 
praktek yang serupa dengan perbudakan, pelayanan secara paksa atau pengambilan organ tubuh;

b) Persetujuan dari seorang korban perdagangan orang atas eksploitasi sebagaimana yang diuraikan dalam huruf (a) pasal ini tidak akan relevan jika salah satu cara yang dijelaskan dalam huruf (a) telah digunakan;

c) Perekrutan, transportasi, pemindahan tangan, penyembunyian seorang anak untuk tujuan eksploitasi akan dianggap sebagai "perdagangan orang" bahkan jika hal tersebut tidak melibatkan cara sebagaimana dijelaskan dalam huruf (a) pasal ini;

d) "Anak" adalah semua orang yang berada di bawah umur delapan belas tahun.

Mengacu pada definisi di atas, ada tiga unsur yang saling terkait yang harus ada secara kumulatif agar perdagangan orang dapat dikatakan telah terjadi, yaitu: proses, cara, serta tujuan. Mengacu pada definisi dalam Protokol Palermo, pendefinisian "korban perdagangan orang" sebagai berikut: ${ }^{13}$

" Seseorang yang telah direkrut, dikirim ke suatu tempat, dipindahkan, ditampung atau diterima, melalui:

a) Diancam

b) Dipaksa dengan kekerasan

c) Dipaksa dengan cara-cara lain

d) Diculik

e) Korban pemalsuan

f) Ditipu

g) Disiksa/dianiaya

h) Dijual, atau

i) "disewakan" untuk mendapatkan keuntungan atau pembayaran tertentu.

\section{Batas Usia Yang Dibawah Ketentuan Sebagai Pekerja}

Bagi anak, seseorang yang belum mencapai usia 18 tahun, persetujuan harus dianggap tidak relevan, dalam arti tidak perlu dibuktikan. Pasal 3 subayat c Protokol Palermo mengakui situasi khusus anak, dimana menghilangkan adanya unsur "cara" sebagai syarat keharusan untuk terjadinya perdagangan orang.

Protokol Palermo menegaskan, bahwa sepanjang berkaitan dengan anakanak sebagai korban, tidak satupun dari cara-cara pemaksaan atau penipuan perlu digunakan untuk membuktikan ada/tidaknya perdagangan orang. Artinya, tidak diperlukan tidak perlu adanya "ancaman atau penggunaan kekerasan atau bentuk lain pemaksaan, penculikan, pemalsuan, penipuan ...". Seorang anak yang telah direkrut, dikirim, dipindahkan dari satu tempat ke tempat lain, ditampung atau diterima untuk tujuan eksploitasi haruslah dikategorikan sebagai seorang", korban perdagangan orang" meskipun anak tersebut tidak diancam, dipaksa, diculik, ditipu, dianiaya, dijual ataupun disewakan.

Oleh karenanya, dapat dikatakan bahwa sub paragraf (c) Protokol Palermo memberikan jaminan pengakuan dan penghormatan hak asasi anak (child rights), dimana secara khusus hal ini relevan menjadi pedoman bagi negara dalam memperlakukan anak korban perdagangan manusia

\section{P E N U T U P}

Bahwa aturan yang diatur dalam UU No 13 Tahun 2003 merupakan wujud dari perlindungan negara terhadap pekerja outsourcing namun dalam menjalankannya seringkali terdapat kesenjangan dimana pekerja outsorcing merasa di tuntut untuk bekerja dengan keras dalam waktu yang berlebih namun upah tidak sesuai yang di kerjakan, hal ini merupakan sesuatu yang dianggap sebagai eksploitasi dalam bekerja, dari 
penepatan kerja yang tidak tepatpun membuat pekerja merasa dibohongi namun dalam perjanjian pekerjaan pekerja berkedudukan yang sangat lemah karena antara pihak outsourcer dan pihak pengguna jasa outsoucing saja yang berperan dalam perjanjian kerja tersebut, UU No 21 tahun 2007 mengisyaratkan supaya hak kemanusiaan manusia tidak boleh dilanggar termaksud hak dalam mendapatkan perlakuan yang manusiawi.

\section{DAFTAR PUSTAKA}

Damanik, Sehat. (2006). Outsourcing \& Perjanjian Kerja menurut UU. No.13 Tahun 2003 tentang Ketenagakerjaan, Jakarta: DSS Publishing.

Hernoko, Agus Yudha. (2010). Hukum Perjanjian Asas Proporsionalitas dalam Kontrak Komersial, Jakarta: Kencana Prenada Media Group.

Jehani, Libertus. (2006). Hak-Hak Pekerja Bila di PHK, Jakarta: Visimedia.

Kosidin, Koko. (1999). Perjanjian Kerja Perjanjian Perburuhan dan Peraturan Perusahaan, Bandung: Mandar Maju.

Ramli, Lanny. (2008). Hukum Ketenagakerjaan, Surabaya: Airlangga University Press.

Subekti, R. (1977). Aneka Perjanjian, Bandung: Alumni.

Samaloisa, Rinto W. (2016). Outsourcing Kontradiksi antara Konsep Hukum dan Praktik, Jakarta: Media Nusa Creative.

\section{Lain-Lain}

Hidayati, Maslihati Nur. (2012). "Upaya Pemberantasan dan Pencegahan Perdagangan Orang melalui
Hukum Internasional dan Hukum Positif di Indonesia", Jurnal Al Azhar Indonesia, Seri Pranata Sosial, Vol 1 No 3, Maret.

Muladi. (1990) Proyeksi Hukum Pidana Materiil Di Indonesia Masa Mendatang, Pidato Pengukuhan Guru Besar, (Semarang: Universitas Diponegoro). 